\title{
Apparent digestibility of pacu (Piaractus mesopotamicus) diets containing different levels of phosphorus
}

\section{Digestibilidade aparente de rações contendo diferentes níveis de fósforo para o pacu (Piaractus mesopotamicus)}

\author{
Juliana Alice Lösch Nervis ${ }^{1 *}$; Aldi Feiden²; Evandro Bilha Moro ${ }^{3}$; \\ Marlon Casarini Moreno ${ }^{3}$; Sidnei Klein; Wilson Rogério Boscolo ${ }^{5}$
}

\begin{abstract}
The present study aimed to evaluate pacu (Piaractus mesopotamicus) diets and determine the apparent digestibility at different levels of phosphorus using the feces collection method with an intestinal dissection marker. A total of 320 pacu with average weights of $768.5 \pm 36.34 \mathrm{~g}$ were used, and they were distributed in four $5 \mathrm{~m}^{3}$ net cages. The fish were fed isonitrogenous $(27 \%)$, isoenergetic $(3000$ $\mathrm{kcal} / \mathrm{kg}$ ) and isocalcium $(1.50 \%$ ) diets with total phosphorus levels of $0.6,0.8,1.0$ and $1.2 \%$. The fish were incised with lateral openings to allow for feces removal from the rectum, and the fish were then sent for carcass chemical composition analysis. Significant differences were observed $(\mathrm{P}<0.01)$ between treatments for the apparent diet digestibility, apparent phosphorous digestibility, available phosphorus and residual phosphorus. There was a linear decrease in apparent diet digestibility and apparent phosphorus digestibility with increasing levels of phosphorous in the diet, and the highest values were observed for the diet with $0.6 \%$ total phosphorus. For available phosphorus and residual phosphorus, there was a linear increase based on total phosphorus levels in the diet. No significant differences were observed for the chemical composition of the pacu carcasses. Therefore, the greatest digestibility of total phosphorus in the diet obtained through dissection was observed in the diet containing $0.6 \%$ total phosphorus, and the different levels of phosphorus did not influence the chemical composition of the pacu carcasses.
\end{abstract}

Key words: Aquaculture, nutrition, minerals, nutrients

\section{Resumo}

O presente estudo teve como objetivo avaliar a digestibilidade aparente de rações contendo diferentes níveis de fósforo para pacus (Piaractus mesopotamicus), através do método de coleta de fezes com

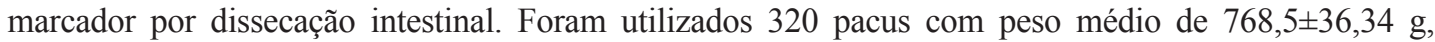
distribuídos em quatro tanques-rede com capacidade de $5 \mathrm{~m}^{3}$. Os peixes foram alimentados com rações isoprotéicas (27\%), isoenergéticas (3000 kcal $/ \mathrm{kg}$ ) e isocálcicas $(1,50 \%)$, com níveis de 0,$6 ; 0,8 ; 1,0$ e 1,2\% de fósforo total. As coletas de fezes foram realizadas, por abertura lateral nos peixes, para retirada das

\footnotetext{
${ }^{1}$ Engenheira de Pesca, Discente do Curso de Doutorado, Programa de Pós-Graduação em Zootecnia, Universidade Estadual de Maringá, UEM, Maringá, PR, Brasil. E-mail: juli.losch@gmail.com

${ }^{2}$ Eng $^{\circ}$ Agr $^{\circ}$, Prof. Dr., Programa de Pós-Graduação em Recursos Pesqueiros e Engenharia de Pesca, Universidade Estadual do Oeste do Paraná, UNIOESTE, Toledo, PR, Brasil. E-mail: aldifeiden@gmail.com

${ }^{3}$ Discentes do Curso de Graduação em Engenharia de Pesca, UNIOESTE, Toledo, PR, Brasil. E-mail: evandrobilha@gmail.com; marloncasarini@yahoo.com.br

${ }^{4}$ Engenheiro de Pesca, Prof. Dr., Instituto Federal do Mato Grosso do Sul, IFMS, Coxim, MS, Brasil. E-mail: skpesca@hotmail.com

5 Zootecnista, Prof. Dr., Programa de Pós-Graduação em Recursos Pesqueiros e Engenharia de Pesca, UNIOESTE, Toledo, PR, Brasil. E-mail: wilsonboscolo@hotmail.com

* Author for correspondence
} 
fezes presente no reto, e os peixes encaminhados para análise de composição centesimal da carcaça. Foram observadas diferenças significativas $(\mathrm{P}<0,01)$ entre os tratamentos para o coeficiente de digestibilidade aparente da dieta, digestibilidade aparente do fósforo, fósforo disponível e fósforo residual. Observou-se uma diminuição linear para digestibilidade aparente da dieta e para digestibilidade aparente do fósforo com o aumento dos níveis de inclusão de fósforo na ração, sendo os maiores valores observados para a dieta com $0,6 \%$ de fósforo total na ração. Para fósforo disponível e fósforo residual houve aumento linear em função dos níveis de fósforo total na ração. Não foram observadas diferenças significativas para a composição centesimal da carcaça dos pacus. Portanto, a maior digestibilidade do fósforo total da dieta, obtida através do método de dissecação, foi observada na dieta contendo $0,6 \%$ de fósforo total para pacu e os diferentes níveis de fósforo não influenciaram na composição química da carcaça de pacus.

Palavras-chave: Aquicultura, nutrição, minerais, nutrientes

\section{Introduction}

Brazil has great potential in aquaculture, and commercial fish farming is primarily based on semi-intensive production systems for exotic species, particularly tilapia (Oreochromis niloticus). However, Brazilian aquaculture is experiencing a significant increase in native fish farming, including that of round fish such as tambaqui (Colossoma macromum), pacu (Piaractus mesopotamicus) and tambacu (hybrid of Colossoma macropomum (female) with Piaractus mesopotamicus (male)). According to data from the Department of Fisheries and Aquaculture (Ministério da Pesca e Aquicultura - MPA, 2012) from 2008 to 2010, round fish accounted for $24.6 \%$ production in continental aquaculture, and pacu production increased from $15,190.00$ tons in 2008 to $21,245.10$ tons in 2010 , representing approximately $5 \%$ of the national aquaculture production in this period.

Studies related to the nutrition of these species have received great attention in recent years and enabled the identification of certain nutritional requirements in cultivation systems (BOSCOLO et al., 2011). Advances and modern aquaculture techniques have been promoting the progressive transformation of extensive farms into semiintensive or intensive farms to ensure the economic viability of the activity. Until recently, extensive fish farming was a common practice; therefore, supplementary food was often used and low fish densities were supported by plankton produced in the environment. The intensification of production will require an increase in the biomass per unit area and supply of nutritionally adequate food.

Feed is an extremely important factor and represents the majority of aquaculture production costs (ABIMORAD; CARNEIRO, 2004); therefore, studies aimed at identifying the nutritional needs of animals have been intensified. Currently, the identification of appropriate levels of protein, carbohydrates, lipids, vitamins and minerals are required for improved growth and economic profitability and reduced environmental impacts.

Among the minerals required by animals, calcium and phosphorus are required at higher levels (ROBINSON et al., 1987). Fish absorb certain minerals dissolved in water (calcium, magnesium, sodium, potassium, iron, zinc, copper and selenium) to meet the species' requirements. However, phosphates, which are found in small amounts in water, must be supplemented in the diet because the use efficiency is low (MOREIRA et al., 2001). According to Furuya et al. (2001), minerals available in the water are insufficient to meet the high levels of dietary requirements imposed by production systems; therefore, these nutrients, especially phosphorus, must be supplemented through the diet. According to Signor et al. (2011) and Diemer et al. (2014), the total dietary phosphorus requirement for pacu ranges from $0.4 \%$ to $0.6 \%$.

Phosphorus is required for the normal maintenance of metabolic and physiological functions, and the lack of an essential mineral in the diet can lead to various signs of deficiency 
(DATO-CAJEGAS; YAKUPITIYAGE, 1996), such as low performance and poor bone mineralization. The digestibility of lipids, carbohydrates and energy is impaired in fish receiving phosphorousdeficient diets (RODEHUTSCORD et al., 2000) because of the important role of phosphorus in storage processes and chemical energy transfer in the body through adenosine triphosphate (ATP) (LEHNINGER et al., 1995). Approximately 85\% the phosphorus in fish is found in the bones and scales (LOVELL, 1988), and it accounts for $16 \%$ of the minerals in bone structures (STEFFENS, 1987). Phosphorus is crucial in growth and cellular differentiation in the formation of phospholipids, it is a component of nucleic acids, and it participates in maintaining acid-base and osmotic equilibrium (ANDRIGUETTO et al., 2002).

Virtually all foods contain a certain amount of phosphorus, but its availability varies between different ingredients (HEPHER, 1988). In the diet, only the available fraction of phosphorus should be considered, and this fraction can often be a small portion of the total phosphorus. Fish that do not receive diets with the necessary amount of phosphorus required for metabolism present retarded growth, anorexia, deteriorated feed conversion and impaired bone formation (LALL, 2002).

Information on phosphorous requirements for each species and its availability in food is essential for the formulation of low-cost diets that minimize excretion into the environment (PEÑAFLORIDA, 1999; WEISMANN et al., 1988). According to Roy et al. (2002), potential environmental impacts of wastewater from fish farming are directly related to the quantity and quality of phosphorus in diets provided to farmed fish. However, data in the literature on the demand and biological value of feed and inorganic sources of phosphorous for fish are scarce, especially with regard to native Brazilian species.

The evaluation of a food's digestibility is an important method of obtaining its nutritional value for use in formulating nutritionally complete fish diets. Digestibility values can be influenced by the conditions and methodologies used in experiments on digestibility. The decanting method is frequently used in digestibility experiments; however, feces fragmentation and component leaching can occur with this technique and contribute to overestimating digestibility values (GLENCROSS et al., 2007). An alternative technique that avoids losses of nutrients because of leaching is intestinal dissection, which involves removing fish from the water and collecting stool samples directly in the posterior region of the intestine (ROSTAGNO; SAKOMURA, 2007).

Limited studies have been conducted in Brazil on digestibility and phosphorus requirements in the various phases and systems for farming native species. These studies are needed to increase productive performance in an economically viable manner, ensure proper fish growth and maintain carcass and water quality, thereby enabling sustainable farming, particularly for intensive farming operations.

Thus, the present study aimed to evaluate pacu diets to determine the apparent digestibility at different levels of phosphorous using the intestinal dissection method and ascertain the influence of such diets on body composition.

\section{Material and Methods}

The experiment was approved by the bioethics committee and conducted in accordance with the technical standards for biosafety and ethics (Experimental Certificate in Animal Use in Research $N^{\circ} 19 / 2014$, regarding Protocol N²6/2013, Ethics Committee on Animal Use - Comitê de Ética no Uso de Animais - CEUA/Unioeste).

The present study was conducted in the Center of Technology for fish farming in net cages, which is located in the Itaipu Reservoir near the Biological Refuge of the City of Santa Helena, Paraná State (PR). This refuge belongs to the Unioeste Study Group on Managing Aquaculture (Grupo de 
Estudos de Manejo em Aquicultura da Unioeste GEMAq) of the State University of West Paraná/ Toledo Campus (Universidade Estadual do Oeste do Paraná/Campus Toledo).

The experiment was conducted with 320 adult pacu that had average weights of $768.5 \pm 36.34 \mathrm{~g}$ and were distributed in four net cages, each housing 80 fish. The net cages had a volume of $5 \mathrm{~m}^{3}$, and each cage received a treatment. Each experimental unit consisted of five animals at the time of feces collection to obtain enough material for analysis.

The treatments consisted of four diets designed to contain levels of $0.60,0.80,1.00$ and $1.20 \%$ total phosphorus (DIEMER et al., 2014). The diets were formulated to be isocaloric $(3000 \mathrm{kcal} /$ $\mathrm{kg}$ ), isoproteic (27\%) and isocalcium (1.50\%) and subjected to extrusion processing in the Feed Processing Factory of GEMAq/Unioeste, Toledo Campus. The treatment of each nutrient in the diet was performed with the aid of the software SuperCrac $^{\circledR}$ 5.7 Master (TD SOFTWARE, 2005). Feeding to apparent satiety was conducted three times a day (DIETERICH, 2011) at 9:00 am, 2:00 $\mathrm{pm}$ and 5:00 pm. The percentage and chemical composition of the diets are shown in Table 1.

Table 1. Percentage and chemical composition of the experimental pacu (Piaractus mesopotamicus) diets with different phosphorus levels.

\begin{tabular}{lcccc}
\hline \multirow{2}{*}{ Ingredients (\%) } & \multicolumn{3}{c}{ Phosphorous levels (\%) } \\
\cline { 2 - 4 } & 0.6 & 0.8 & 1.0 & 1.2 \\
\hline Soybean meal & 41.00 & 41.14 & 41.27 & 41.41 \\
Ground corn & 33.20 & 32.50 & 31.79 & 31.09 \\
Wheat bran & 15.00 & 15.00 & 15.00 & 15.00 \\
Poultry viscera meal & 2.98 & 2.99 & 2.99 & 3.00 \\
Limestone & 2.178 & 2.08 & 1.38 & 0.68 \\
Fish meal & 2.00 & 2.00 & 2.00 & 2.00 \\
Soy oil & 1.31 & 1.51 & 1.70 & 1.90 \\
Vitamin and mineral supplement* & 1.00 & 1.00 & 1.00 & 1.00 \\
Salt & 0.30 & 0.30 & 0.30 & 0.30 \\
L-lysine & 0.14 & 0.14 & 0.14 & 0.14 \\
Propionate & 0.10 & 0.10 & 0.10 & 0.10 \\
Butylated hydroxytoluene & 0.02 & 0.02 & 0.02 & 0.02 \\
Bicalcium phosphate & 0.00 & 1.08 & 2.17 & 3.25 \\
Chrome & 0.10 & 0.10 & 0.10 & 0.10 \\
Total & 100.00 & 100.00 & 100.00 & 100.00 \\
\hline Nutrients & & & & 23.90 \\
\hline Starch (\%) & 25.20 & 24.76 & 24.33 & 1.50 \\
\hline Calcium (\%) & 1.50 & 1.50 & 1.50 & 3.000 \\
Digestible energy (Kcal/Kg) & 3.000 & 3.000 & 3.000 & 1.20 \\
Total phosphorous (\%) & 0.60 & 0.80 & 1.00 & 4.28 \\
Fat (\%) & 3.78 & 3.95 & 4.12 & 1.64 \\
Total lysine (\%) & 1.64 & 1.64 & 1.64 & 0.42 \\
Methionine (\%) & 0.42 & 0.42 & 0.42 & 27.00 \\
Crude protein (\%) & 27.00 & 27.00 & 27.00 & \\
\hline
\end{tabular}

* Vitamin and mineral supplement: Guaranteed levels per kilogram of product: Vit. A. 24,000 IU; Vit. D3, 6,000 IU; Vit. E, 300 mg; Vit. K3, 30 mg; Vit. B1, 40 mg; Vit. B2, 40 mg; Vit. B6, 35 mg; Vit. B12, 80 mg; Folic Acid, 12 mg; Ca Pantothenate, 100 mg; Vit. C, 600 mg; Biotin, 2 mg; Choline, 1,000 mg; Niacin; Iron, 200 mg; Copper, 35 mg; Manganese, 100 mg; Zinc, 240 mg; Iodine, 1.6 mg; Cobalt, $0.8 \mathrm{mg}$; Vitamin $\mathrm{C}$ monophosphate containing $35 \%$ ascorbic acid. 
After a seven-day adaptation period, fish were fed for 45 and 60 before the first and second sample collections, respectively, for a total of 60 days in the experiment. To collect the samples using intestinal dissection, 20 fish were caught from each treatment and euthanized with benzocaine $(250 \mathrm{mg}$ $\mathrm{L}^{-1}$ ) following the protocol by Gomes et al. (2001). The carcasses were then placed in a cooler with water and ice and transported to the Fish Processing Laboratory of GEMAq/Unioeste, Toledo Campus. In the laboratory, the fish were weighed and opened laterally to remove the fecal content.

The distal portion of the intestine behind the second intestinal valve was removed from the fish and placed in a Petri dish. The intestine was opened longitudinally with the aid of surgical scissors, and the fecal contents were removed with a spatula and transferred to another Petri dish (ABIMORAD; CARNEIRO, 2004). A "pool" of the stool samples was made from every five fish to provide a sufficient

$$
T D D=100-100\left(\frac{\% D I}{\% F I}\right) \text { and }
$$

where

$\mathrm{TDD}=$ total test diet digestibility (\%);

AND $=$ apparent nutrient digestibility of the test diets $(\%)$;

$$
\begin{aligned}
& \mathrm{DI}=\text { diet indicator; } \\
& \mathrm{FI}=\text { feces indicator; } \\
& \mathrm{FN}=\text { feces nutrient; and } \\
& \mathrm{DN}=\text { diet nutrient. }
\end{aligned}
$$

The fish from which fecal samples were taken were then gutted, washed and packed in sample packages and frozen for posterior chemical composition analysis, including analyses of the carcass dry matter, mineral matter, crude protein, lipid and phosphorus. The chemical composition analysis was conducted at LQA/Unioeste. The samples were pre-dried in an forced-air oven at $55^{\circ} \mathrm{C}$ amount to perform the analyses, and four replicates were performed for each treatment.

The collected fecal samples were sent to the Laboratory of Food Quality Control (Laboratório de Controle de Qualidade de Alimentos - LQA) of GEMAq/Unioeste, Toledo Campus. The samples were pre-dried in a forced-air oven at $55^{\circ} \mathrm{C}$ for 72 hours, and after drying, they were stored in plastic bags for further analysis. In the laboratory, analyses of the dry matter were conducted, and a nitropercloric opening was incised. The samples were then sent for a chrome reading according to the methodology of Kimura and Miller (1957) and phosphorus reading at the Laboratory of Atomic Absorption Spectrophotometry at the Unioeste Chemical Engineering Program.

To calculate the total diet digestibility (TDD) of the dry matter and phosphorus availability (AND), the equations indicated by the National Research Council (NRC, 1993) were used.

$A N D=100-100\left(\frac{\% D I}{\% F I} \times \frac{\% F N}{\% D N}\right)$

for 72 hours and then ground in a multiprocessor and homogenized to determine the dry matter (oven at $105^{\circ} \mathrm{C}$ for $8 \mathrm{~h}$ ), lipid (Sohxlet extractor), crude protein (Micro-Kjeldahl) and ash content (incineration in a furnace at $550^{\circ} \mathrm{C}$ for 4 hours) according to the analytical standards of the Adolfo Lutz Institute (INSTITUTO ADOLFO LUTZ, 2005).

To monitor water quality, three water samples were collected between the net cages and around the aquaculture area. The temperature was monitored daily in the morning at 9:00 am and afternoon at 5:00 pm. The dissolved oxygen and $\mathrm{pH}$ of the water samples were evaluated by portable Hanna Instruments $^{\circledR}$ potentiometers. The water samples were collected, preserved in dark polyethylene bottles and kept refrigerated for posterior total phosphorus, orthophosphate and total nitrogen 
analyses, which were conducted at LQA/Unioeste.

The data were analyzed for normality (ShapiroWilk) and homogeneity of variance (Levene), and in the case of differences, Tukey's test was performed using the statistical software SAEG (Sistema de Análises Estatísticas e Genéticas - System for Statistical and Genetic Analyses) (UFV/SAEG, 1997).

\section{Results and Discussion}

The average temperature, $\mathrm{pH}$ and dissolved oxygen values in the water were $24.5 \pm 2.04^{\circ} \mathrm{C}$; $7.23 \pm 0.18$ and $7.50 \pm 0.18 \mathrm{mg} \mathrm{L}^{-1}$, respectively. These average values are within the recommended range for the production of tropical fish (BOYD, 1990; SIPAÚBA-TAVARES, 1995). The total phosphorus was $0.065 \pm 0.003 \mathrm{mg} \mathrm{L}^{-1}$, which is close to the value observed by Diemer et al. (2010), who conducted a nictimeral and vertical evaluation of the limnological characteristics of the experimental aquaculture area; however, this value is above the value recommended by the National Environmental Council (CONAMA Conselho Nacional do Meio Ambiente) Resolution $n^{\circ} 357 / 2005$. Total nitrogen was $0.115 \pm 0.037 \mathrm{mg} \mathrm{L}-1$, which was within the limit of CONAMA Resolution $n^{0}$ 357/2005.

Abimorad and Carneiro (2004) indicated that they had difficulty obtaining the minimum amounts of stool required to analyze the chromium oxide and protein contents in duplicate using the intestinal dissection and manual extrusion methods. This difficulty also occurred in the present study, in which approximately two grams of dry matter was obtained from the feces for every five fish, forming an experimental unit.

The different dietary phosphorus levels affected the total diet digestibility, apparent phosphorus digestibility, apparent protein digestibility, available phosphorus and residual phosphorus (Table 2).

Table 2. Coefficient of apparent phosphorus digestibility for pacu (Piaractus mesopotamicus) diets containing different levels of phosphorous.

\begin{tabular}{lccccc}
\hline \multirow{2}{*}{\multicolumn{1}{c}{ Variables (\%) $^{*}$}} & \multicolumn{3}{c}{ Levels of phosphorous in the diet (\%) } & \multirow{2}{*}{ VC (\%) } \\
\cline { 2 - 4 } & 0.6 & 0.8 & 1.0 & 1.2 & \\
\hline Total diet digestibility $^{1}$ & $80.36_{\mathrm{a}}$ & $77.54_{\mathrm{ab}}$ & $78.41_{\mathrm{ab}}$ & $73.87_{\mathrm{b}}$ & $2.25^{* *}$ \\
Apparent digestibility of phosphorous $^{2}$ & $70.50_{\mathrm{a}}$ & $58.55_{\mathrm{b}}$ & $50.72_{\mathrm{c}}$ & $44.25_{\mathrm{d}}$ & $4.16^{* *}$ \\
Apparent digestibility of protein $^{3}$ & $86.26_{\mathrm{a}}$ & $83.91_{\mathrm{ab}}$ & $85.67_{\mathrm{a}}$ & $82.67_{\mathrm{b}}$ & $1.23^{* *}$ \\
Available phosphorous $^{4}$ & $0.42_{\mathrm{c}}$ & $0.47_{\mathrm{bc}}$ & $0.51_{\mathrm{ab}}$ & $0.53_{\mathrm{a}}$ & $4.58^{* *}$ \\
Residual phosphorous $^{5}$ & $0.18_{\mathrm{d}}$ & $0.33_{\mathrm{c}}$ & $0.49_{\mathrm{b}}$ & $0.67_{\mathrm{a}}$ & $5.29 * *$ \\
\hline
\end{tabular}

** $\mathrm{P}<0.01 ;{ }^{1}$ Linear effect $\left(\mathrm{y}=85.9231-0.9305 \mathrm{x} ; \mathrm{r}^{2}=0.78\right) ;{ }^{2}$ Linear effect $\left(\mathrm{y}=94.9708-4.3292 \mathrm{x} ; \mathrm{r}^{2}=0.98\right) ;{ }^{3}$ Linear effect $(\mathrm{y}=88.6859$ $\left.0.4510 x ; r^{2}=0.50\right) ;{ }^{4}$ Linear effect $\left(y=3.1916+0.1814 x ; r^{2}=0.98\right) ;{ }^{5}$ Linear effect $\left(y=-0.3192+0,0818 x ; r^{2}=0.99\right)$.

A linear effect was observed for the diet's apparent digestibility and coefficient of apparent phosphorus digestibility (Figure 1), with the highest mineral digestibility of $70.50 \%$ in the treatment with $0.6 \%$ total phosphorus and lowest mineral digestibility of $44.25 \%$ for the treatment with $1.2 \%$ total phosphorus. Oliveira et al. (2011) also observed a decline in total diet digestibility and phosphorus digestibility with different levels of available phosphorus in the diets for tilapia. 
Figure 1. Linear effect between the apparent digestibility of phosphorous and treatments.

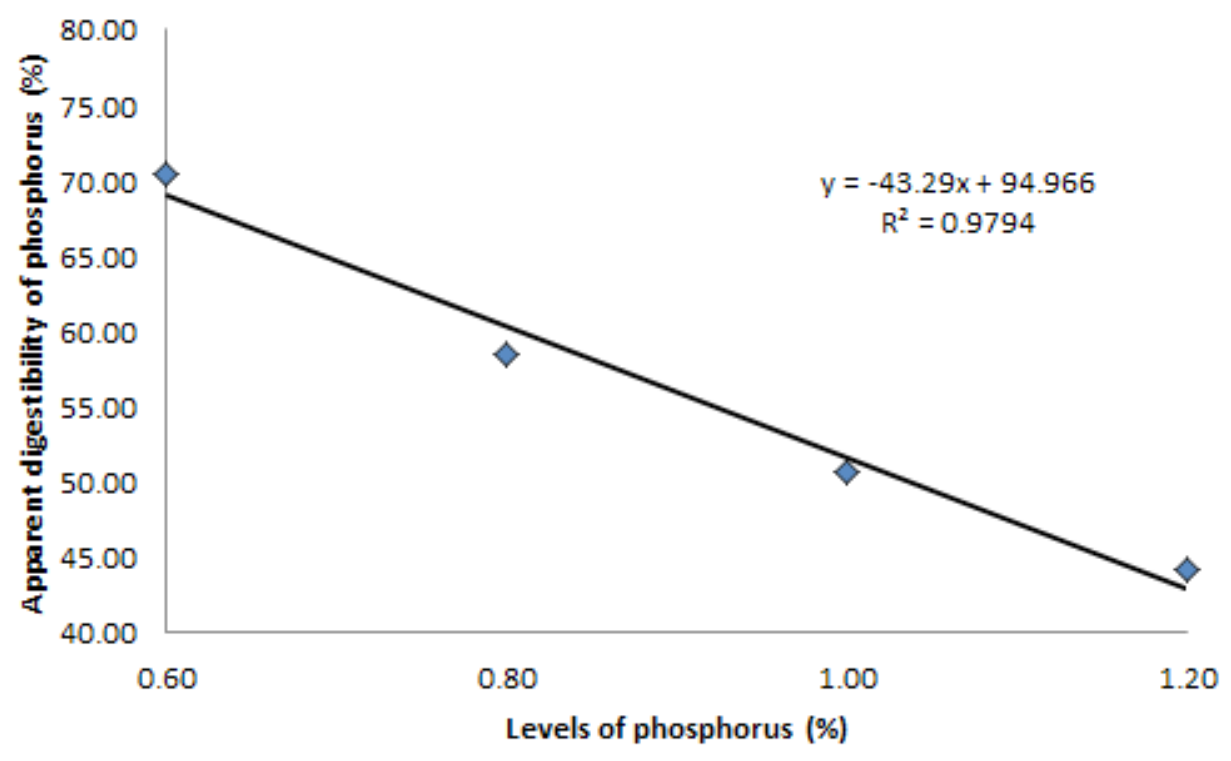

In Figure 2, the available phosphorus and residual phosphorus values were converted to $\mathrm{g} \mathrm{kg}^{-}$ 1, and higher phosphorus availability was observed with the inclusion of higher levels of phosphorus in the diet; however, greater phosphorus excretion by the fish was also observed.

Figure 2. Linear effect between available phosphorous, residual phosphorous and treatments.

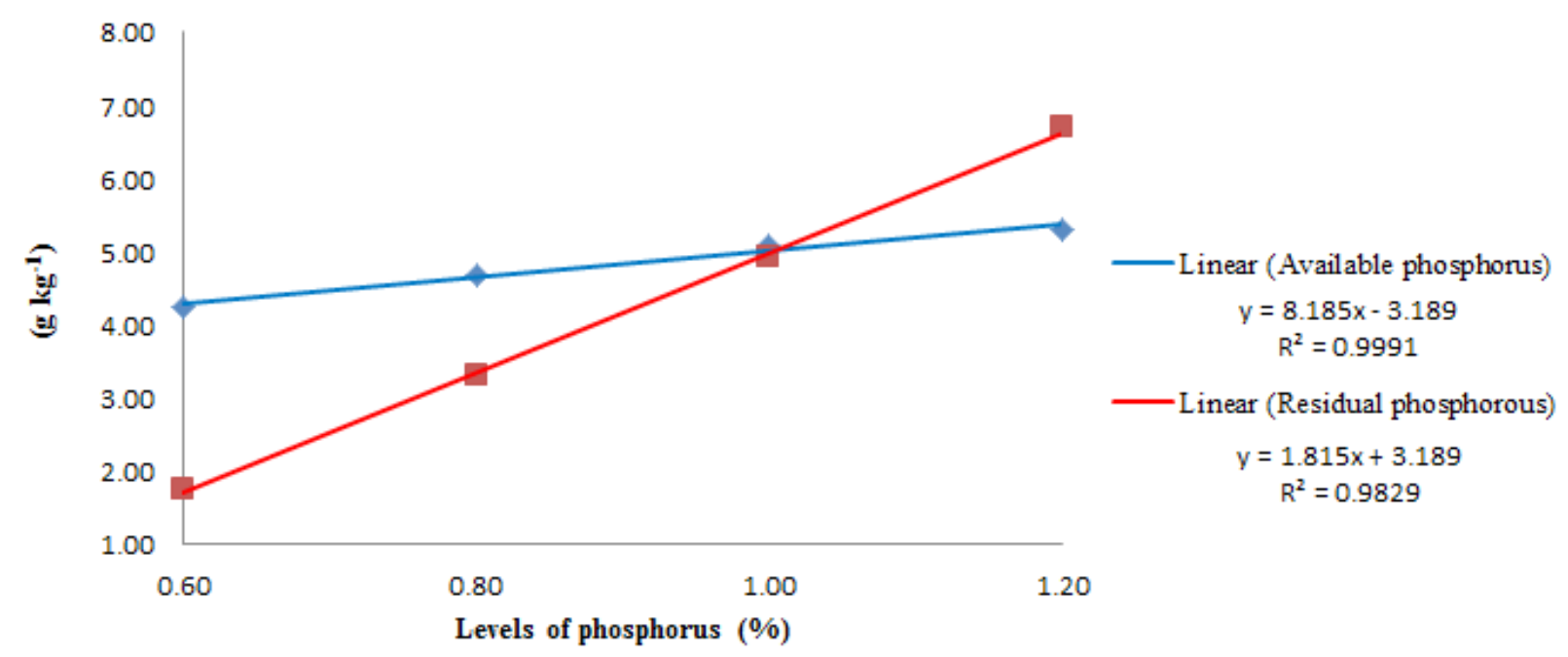

Residual phosphorus presented a linear effect and increased based on phosphorus inclusion levels. Similar data were observed by Furuya et al. (2008), who studied the availability of this mineral for tilapia and indicated that the excretion of fecal phosphorus per $\mathrm{kg}$ of produced fish increased linearly with available phosphorus levels of 0.25 , $0.35,0.45$ and $0.55 \%$. The data from the present 
study are also in accordance with Oliva-Teles and Pimentel-Rodrigues (2004), which shows that diets with available phosphorus values above the requirements for pacu $(0.4 \%$ to $0.6 \%$ according to Signor et al. (2011) and Diemer et al. (2014), respectively) are not required. However, to obtain formulations with levels below $0.6 \%$, feeds with large quantities of animal-derived ingredients, which often enjoy high availability and low cost in the market and include meat and bone meal and other by-products of agro-industrial meat processers, should be avoided.

The increase in phosphorus levels reduced the coefficient of apparent protein digestibility. Oliveira et al. (2011) also found that an increase in dietary phosphorus produced a linear reduction in the digestibility of dry matter and protein in the diet of Nile tilapia. Austreng (1978) reported that during fish dissection, pressure and injuries in the gut could occasionally occur, thereby causing the addition of endogenous nitrogen (mucus and epithelial cells) to the stool, which can decrease values of protein digestibility.

The different levels of phosphorous in the diet did not affect the chemical composition of the pacu carcasses, and significant differences were not observed for water content, crude protein, lipids, mineral matter and phosphorus (Table 3).

Table 3. Chemical composition (g per $100 \mathrm{~g}$ ) of pacu (Piaractus mesopotamicus) (carcasses) fed diets containing different levels of phosphorous.

\begin{tabular}{lcccccc}
\hline \multirow{2}{*}{ Variables (\%) } & \multirow{2}{*}{ Initial sample } & \multicolumn{4}{c}{ Levels of phosphorous in diet (\%) } & \multirow{2}{*}{ VC (\%) } \\
\cline { 3 - 6 } & & 0.6 & 0.8 & 1.0 & 1.2 & \\
\hline Water content & 61.69 & 62.68 & 62.02 & 64.12 & 63.22 & $2.48^{\text {ns }}$ \\
Crude protein & 16.48 & 16.42 & 16.51 & 15.72 & 16.09 & $7.90^{\text {ns }}$ \\
Lipids & 15.52 & 17.02 & 17.36 & 15.92 & 16.89 & $7.98^{\text {ns }}$ \\
Mineral matter & 4.70 & 4.86 & 4.71 & 4.81 & 4.32 & $11.79^{\text {ns }}$ \\
Phosphorous & 0.72 & 0.73 & 0.77 & 0.75 & 0.72 & $12.52^{\text {ns }}$ \\
\hline
\end{tabular}

${ }^{n s}$ Not significant

The chemical composition values ranged from 62.02 to $64.12 \%$ water-content, 15.72 to $16.51 \%$ protein, and 15.92 to $17.36 \%$ lipids and are consistent with those described by Ogawa and Maia (1999) and Tavares and Gonçalves (2011). These authors described the composition of fish muscle and noted values ranging from 60 to $85 \%$ water content, approximately $20 \%$ protein, 0.6 to $36 \%$ lipids and 1 to $2 \%$ mineral matter or ash. In the present study, only mineral matter values (ranging from 1 to $2 \%$ ) were above the values described by these authors, whereas in the present study, these values ranged from 4.32 to $4.86 \%$. It is noteworthy that the entire carcass, including the head, was used for the chemical composition analyses, which may have influenced the amount of phosphorus. The phosphorous values in the carcass were close to those found by Dieterich et al. (2012), who evaluated different sources of phosphorus for Nile tilapia fry and juveniles and used the whole fish in the chemical composition analysis. The water content, protein and lipid values were close to the values observed by Diemer et al. (2014), who evaluated different levels of phosphorus in feed for pacu.

The water content, crude protein and mineral matter values were close to those observed by Signor et al. (2011), who evaluated the chemical composition of pacu carcasses that were fed diets with different phosphorus levels ranging from 0.4 to 
$1.0 \%$. However, phosphorous values in the carcasses were higher in the present study (approximately $0.7 \%$ ) than those observed by Signor et al. (2011), who observed values of approximately $0.4 \%$. It is important to highlight that the fish in the two studies were of different ages and weights.

The crude protein and mineral matter values were also close to the values reported by Furuya et al. (2008), who evaluated diets containing increasing levels of available phosphorus ranging from 0.25 to $0.55 \%$. The water content values observed by the author were higher, whereas lipid levels were lower because chemical compositions can vary between species, age, sex, seasonality and physiological state (TAVARES; GONÇALVES, 2011). Pacu has a higher fat content compared to tilapia, and there is an inverse relationship between water content and fat; thus, fish with higher fat content have lower water content (OGAWA; MAIA, 1999; TAVARES; GONÇALVES, 2011).

In this study, the dissection method was used on pacu fed diets with varying total phosphorus, and the highest total phosphorous digestibility was observed for diets containing $0.6 \%$ total phosphorus. In addition, different levels of phosphorus did not influence the chemical composition of the fish carcasses.

\section{Acknowledgements}

The author would like to thank the Itaipu Binacional and Brazilian National Council for Scientific and Technological Development (Conselho Nacional de Desenvolvimento Científico e Tecnológico - CNPq).

\section{References}

ABIMORAD, E. G.; CARNEIRO, D. J. Métodos de coletas de fezes e determinação dos coeficientes de digestibilidade da fração proteica e da energia de alimentos para o pacu, Piaractus mesopotamicus (Holmberg, 1887). Revista Brasileira de Zootecnia, Viçosa, MG, v. 33, n. 5, p. 1101-1109, 2004.
ANDRIGUETTO, J. M.; PERLY, L.; MINARDI, I.; GEMAEL, A.; FLEMMING, J. S.; SOUZA, G. A. BONA, A. F. Os minerais na nutrição animal. In:

Nutrição animal. São Paulo: Nobel, 2002. v. 1, p. 173255.

AUSTRENG, E. Digestibility determination in fish using chromic oxide marking and analysis of contentes from different segments of the gastrointestinal tract. Aquaculture, Amsterdam, v. 13, n. 3, p. 265-272, 1978.

BOSCOLO, W. R.; SIGNOR, A.; FREITAS, J. M. A.; BITTENCOURT, F.; FEIDEN, A. Nutrição de peixes nativos. Revista Brasileira de Zootecnia, Viçosa, MG, v. 40, p. 145-154, 2011. Suplemento Especial.

BOYD, E. Water quality in ponds for aquaculture. Auburn: Auburn University, 1990. 482 p.

CONAMA - Conselho Nacional de Meio Ambiente. Resolução, nº 357, de 17 de março de 2005. Dispõe sobre a classificação dos corpos de água e diretrizes ambientais para o seu enquadramento, bem como estabelece as condições e os padrões de lançamento de efluentes, e dá outras providências. DOU $\mathrm{N}^{\circ} 053$ de 18 mar. 2005, Brasília, p. 58-63. Disponível em: <http://www.mma. gov.br/port/conama/res/res05/res35705.pdf $>$. Acesso em: 28 jan. 2013

DATO-CAJEGAS, C. R. S.; YAKUPITIYAGE, A. The need dietary mineral suplementation for Nile tilapia, Oreochromis niloticus, cultured in a semi-intensive system. Aquaculture, Amsterdam, v. 144, n. 1-3, p. 227327, 1996.

DIEMER, O.; NEU, D. H.; FEIDEN, A.; LORENZ, E. K.; BITTENCOURT, F.; BOSCOLO, W. R. Dinâmica nictimeral e vertical das características limnológicas e ambiente de criação de peixes em tanques-rede. Ciência Animal Brasileira, Goiânia, v. 11, n. 1, p. 24-31, 2010.

DIEMER, O.; BOSCOLO, W. R.; SIGNOR, A.A.; KLEIN, S.; FEIDEN, A. Fósforo na alimentação de pacus criados em tanques-rede. Arquivo Brasileiro de Medicina Veterinária e Zootecnia. Belo Horizonte, MG, v. 66, n. 4, p. 1243-1250, 2014.

DIETERICH, F.; BOSCOLO, W. R.; LÖSCH, J. A.; FEIDEN, A.; FURUYA, W. M.; SIGNOR, A. A. Fontes de fósforo em rações orgânicas para alevinos e juvenis de tilápia do Nilo. Pesquisa Agropecuária Brasileira, Brasília, v. 47, n. 3, p. 417-424, 2012.

DIETERICH, T. G. Frequência de arraçoamento para juvenis de pacu (Piaractus mesopotamicus) em tanquesrede. 2011. Dissertação (Mestrado em Zootecnia) Universidade Estadual do Oeste do Paraná, Marechal Cândido Rondon. 
FURUYA, W. M.; FUJII, K. M.; SANTOS, L. D.; SILVA, T. S. C.; SILVA, L. C. R.; SALES, P. J. P. Exigência de fósforo disponível para juvenis de tilápia do Nilo. Revista Brasileira de Zootecnia, Viçosa, MG, v. 37, n. 9, p. 15171522, 2008.

FURUYA, W. M.; GONÇALVES, G. S.; FURUYA, V. R. B.; HAYASHI, C. Fitase na alimentação de tilápia do Nilo (Oreochromis niloticus). Desempenho e digestibilidade. Revista Brasileira de Zootecnia, Viçosa, MG, v. 30, n. 3, p. 924-929, 2001. Suplemento 1.

GLENCROSS, B. D.; BOOTH, M.; ALLAN, G. L. A feed is only as its ingredients - a review of ingredient evaluation strategies for aquaculture feeds. Aquaculture Nutrition, Oxford, v. 13, n. 1, p. 17-34, 2007.

GOMES, L. C.; CHIPPARI-GOMES, A. R.; LOPES, N. P.; ROUBACH, R.; ARAUJO LIMA, C. A. R. M. Efficacy of benzocaine as na anesthetic in juvenile tambaqui Colossoma macropomum. Journal of the World Aquaculture Society, New Orleans, v. 32, n. 4, p. 426431, 2001.

HEPHER, B. Nutrition of pond fishes. New York: Cambridge University Press, 1988. 388 p.

INSTITUTO ADOLFO LUTZ - IAL. Normas analíticas do Instituto Adolfo Lutz. Métodos físico-químicos para análise de alimentos. 4. ed. Brasília: Editora MS, 2005. $1018 \mathrm{p}$.

KIMURA, F. T.; MILLER, V. L. Improved determination of chromic oxide in cal feed and feces. Journal Agriculture Food Chemistry, Washington, v. 5, n. 2, p. 216, 1957.

LALL, S. P. The minerals. In: HALVER, J. E.; HARDY, R. W. (Ed.). Fish nutrition. $3^{\text {th }}$ ed. New York: Academic Press, 2002. p. 259-308.

LEHNINGER, A. L.; NELSON, D. L.; COX, M. M. Princípios de bioquímica. São Paulo: SARVIER, 1995. $839 \mathrm{p}$.

LOVELL, T. Nutrition and feeding of fish. New York: Van Nostrand Reinhold, 1988. 260 p.

MOREIRA, H. L. M.; VARGAS, L.; RIBEIRO, R. P.; ZIMMERMANN, S. (Org.). Fundamentos da moderna aquicultura. Canoas: Ed. ULBRA, 2001. 200 p.

MINISTÉRIO DA PESCA E AQUICULTURA - MPA. Boletim estatístico da pesca e aquicultura. Brasília: [s.n], 2012. 129 p.

NATIONAL RESEARCH COUNCIL - NRC. Nutrient requirements of warmwater, fishes and shellfishes: nutrient requirements of domestics animals. Washington: National Academy Press, 1993. 114 p.
OGAWA, M.; MAIA, E. L. Manual de pesca. São Paulo: Varela, 1999. $430 \mathrm{p}$.

OLIVA-TELES, O.; PIMENTEL-RODRIGUES, A. M. P. Phosphorus requirements of European sea bass (Dicentrarchus labrax L.) juveniles. Aquaculture Research, Oxford, v. 35, n. 7, p. 636-642, 2004.

OLIVEIRA, M. M.; ORLANDO, T. M.; LEAL, R. S.; DRUMOND, M. M.; ALLAMAN, I. B.; ROSA, P. V.; PIMENTA, M. E. S. G.; NEIRA, L. M. Digestibilidade e composição química de Oreochromis niloticus alimentados com dietas contendo diferentes níveis de fósforo. Revista Brasileira de Saúde e Produção Animal, Salvador, v. 12, n. 4, p. 1026-1037, 2011.

PEÑAFLORIDA, A. D. Interaction between dietary levels of calcium and phosphorus on growth of juvenile shrimp, Penaeus monodon. Aquaculture, Amsterdam, v. 172, n. 3-4, p. 281-289, 1999.

ROBINSON, E. H.; LABOMASCUS, D.; BROWN, P. B., LINTON, T. Dietary calcium and phosphorus requirements of Oreochromis aureus reared in calciumfree water. Aquaculture, Amsterdam, v. 64, n. 4, p. $267-$ 276, 1987.

RODEHUTSCORD, M.; GREGUS, Z.; PFEFFER, E. Effect of phosphorus intake on faecal and non-faecal phosphorus excretion in rainbow trout (Oncorhynchus mykiss) and the consequences for comparative phosphorus avaibility studies. Aquaculture, Amsterdam, v. 188, n. 3-4, p. 383-398, 2000.

ROSTAGNO, H. S.; SAKOMURA, N. K. Métodos de pesquisa em nutrição de monogástricos. Jaboticabal: FUNEP, 2007. 283 p.

ROY, P. K.; WITTEN, P. E.; HALL, B. K.; LALL, S. P. Effects of dietary phosphorus on bone growth and mineralization of vertebrae in haddock Melanogrammus aeglefinus. Fish Physiology and Biochemistry, v. 27, n. 1-2, p. 35-48, 2002.

SIGNOR, A. A.; FEIDEN, A.; BITTENCOURT, F.; POTRICH, F. R.; DEPARIS, A.; BOSCOLO, W. R. Fósforo na alimentação de pacu (Piaractus mesopotamicus). Revista Brasileira de Zootecnia, Viçosa, MG, v. 40, n. 12, p. 2646-2650, 2011.

SIPAÚBA-TAVARES, L. H. S. Limnologia aplicada à aquicultura. Jaboticabal: Funep, 1995. 72 p.

STEFFENS, W. Princípios fundamentales de la alimentation de los peces. Zaragoza: Editora Acribia S. A., $1987.275 \mathrm{p}$. 
TAVARES, M.; GONÇALVES, A. A. Aspectos físcoquímicos do Pescado. In: GONÇALVES, A. A. (Ed.). Tecnologia do pescado: ciência, tecnologia, inovação e legislação. São Paulo: Editora Atheneu, 2011. 608 p.

TD Software, SuperCrac ${ }^{\circledR}$ : cálculo de ração de custo mínimo. Versão 5. 7 Master, Viçosa: TD Software, 2005.
UNIVERSIDADE FEDERAL DE VIÇOSA - UFV/ SAEG - Sistema de análises estatísticas e genéticas. Versão 7.1. Viçosa, MG: 1997. 150 p. (Manual do usuário).

WEISMANN, D.; SCHEID, H.; PFEFFER, E. Water pollution with phosphorus of dietary origin by intensively fed rainbow trout (Salmo gairdner). Aquaculture, Amsterdam, v. 69, n. 3-4, p. 263-270, 1988. 
